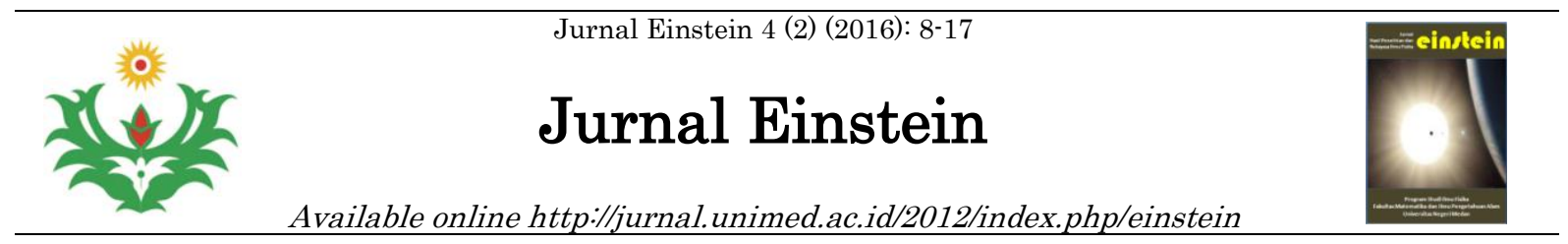

\title{
Penentuan Struktur Bawah Permukaan Daerah Geotermal Menggunakan Metode Geomagnet dan Geolistrik
}

\author{
Wahyu Azhar Ritonga dan Muhammad Kadri* \\ Jurusan Fisika, Fakultas Matematika dan Ilmu Pengetahuan Alam, Universitas \\ Negeri Medan, Indonesia
}

Diterima April 2016; Disetujui Mei 2016; Dipublikasikan Juni 2016

\begin{abstract}
Abstrak
Telah dilakukan penelitian tentang Penentuan Struktur Bawah Permukaan Daerah Geothermal Menggunakan Metode Geomagnet Dan Geolistrik Di Dusun Bahoan Kecamatan Silau Kahean Kabupaten Simalungun. Penelitian ini bertujuan untuk mengetahui kontur penyebaran fluida, penampang anomali dan model lapisan struktur bawah permukaan. Pengukuran metode geomagnet menggunakan PPM (Proton Precession Magnetometer) tipe Elsec 770, pengambilan data dilakukan secara acak dengan jumlah titik yang diperoleh 40 titik ukur, pengolahan data menggunakan surfer 10 untuk mendapatkan peta kontur dan Mag2DC for windows untuk mendapatkan penampang anomali magnetik. Metode geolistrik menggunakan alat Ares-G4 Versi 4,7 (Automatic Resistivity System) dan GPS (Global Position System) pengukuran metode geolistrik dilakukan dengan membentangkan elektroda serta menginjeksi arus melalui dua elektroda dan beda potensial yang muncul dapat terukur sehingga didapat harga resistivitas semu yang diperoleh dari alat geolistrik. Kemudian data diolah menggunakan Res2Div untuk mendapatkan penampang kontur 2D dari nilai resistivitas lapisan batuan. Hasil penelitian menunjukkan bahwa kontur penyebaran fluida menggunakan metode geomagnet dan geolistrik tersebar secara vertikal, penampang anomali dengan metode geomagnet memiliki nilai terendah 22,75 $\mathrm{nT}$ dan nilai tertinggi $69,92 \mathrm{nT}$, dari penampang anomali didapat nilai suseptibilitas 0,00054, 0,0006, 0,0016 dimana model lapisan struktur bawah permukaan terdiri dari batuan pasir, lempung dan gamping. Untuk metode geolistrik memiliki nilai resistivitas (0,00-100) $\Omega m$ dan model lapisan batuan lempung. Nilai resistivitas (150200) $\Omega m$ model lapisan batuan lanau. Nilai restivitas $(350-500) \Omega m$ model lapisan pasir, dan nilai restivitas $>2250 \Omega m$ model lapisan batu gamping.
\end{abstract}

Kata kunci: Geomagnet, Geolistrik, GPS, Suseptabilitas, Resistivity, Geothermal

\section{Abstract}

The Research of Subsurface Structure of Geothermal area determination has been done at Bahoan Silau Kahean Simalungun District, by using geomagnet and geophysics method. The purpose of the research is to detect fluid contur, its anomaly and also 
subsurface structure layer. The geomagnet method use PPM (Proton precession magnetometer) Elsec 770 type, data retrieval is randomly by the number of points earned 40 point measurement, data is processed by using surfers 10 to obtain a contour map and Mag2DC for windows to get a cross-section of the magnetic anomaly. Geoelectric method using a tool Ares-G4 Version 4.7 (Automatic Resistivity System) and GPS (Global Position System) measurement geoelectric method performed by spreading the electrode and injecting the current through two electrodes and the potential difference that appears can be measured in order to get the apparent resistivity obtained of geoelectric tools. The data is processed using Res2Div to acquire $2 D$ cross-sectional contours of the rock layers resistivity values. The results showed that the spread of the fluid contours using geomagnetic and geoelectric spread vertically, sectional geomagnetic anomaly method has the lowest value and the highest value $22.7569 .92 \mathrm{nT} n T$, of the foregoing anomalous values obtained susceptibility 0.00054, 0.0006, 0.0016 where the model subsurface layer structure composed of sandstone, clay and limestone. For geoelectric method has a resistivity values $(0,00$ 100) $\mathrm{\Omega m}$ and clay models of rock layers. Resistivity values (150-200) $\mathrm{\Omega m}$ models silt rock layers. Value restivitas (350-500) $\mathrm{\Omega m}$ sand layer model, and the value restivitas $>$ 2250 Qm limestone layer model.

Keywords: Geomagnetic, Geoelectric, Resistivity, Geothermal

How to Cite: Wahyu Azhar Ritonga dan Muhammad Kadri, (2016), Penentuan Struktur Bawah Permukaan Daerah Geotermal Menggunakan Metode Geomagnet dan Geolistrik, Jurnal Einsten Prodi Fisika FMIPA Unimed, 4 (2): 8-17.

\begin{tabular}{ll}
\hline${ }^{*}$ Corresponding author: & p-ISSN : I2338 - 1981 \\
E-mail : wahyuazharrit@gmail.com & e-ISSN : 2407-747x
\end{tabular}




\section{PENDAHULUAN}

Energi merupakan salah satu faktor pendukung perkembangan kemajuan suatu negara, bilamana suatu negara kekurangan energi maka akan memperlambat perkembangan kemajuan negara serta memperlambat laju mobilitas ekonomi dan menurunkan produksi industri. Salah satu energi yang sangat diperlukan adalah energi listrik. Kebutuhan energi listrik setiap tahun semakin meningkat, pada tahun 2014 di Indonesia mencapai 31.550,95 MW, sedangkan kebutuhan energi listrik yang dibutuhkan oleh Indonesia 50.000,00 MW. Daerah yang mengalami rasio elektrifikasi pasokan listrik yakni Propinsi Papua (36,41\%), Nusa Tenggara Timur (54,77\%), Nusa Tenggara Barat (64,43\%), Kalimantan Tengah (66,21\%), Gorontalo (67,81\%), Sulawesi Barat (67,6\%), Kepulauan Riau (69,66\%) dan Sumatera Utara (89,6\%), khususnya Sumatera Utara sejak tahun 2005, krisis listrik di Sumut tidak kunjung selesai. Saat ini kebutuhan listrik Sumut sebesar $\quad 1.700 \quad$ MW(megawatt), sedangkan kekurangan pasokan sekitar 330 MW. Jumlah ini diluar cadangan daya yang dibutuhkan sebagai cara untuk mengantisipasi jika terjadi gangguan pembangkit (Budiyanti, 2014).

Salah satu energi yang sangat berpotensi untuk dimanfaatkan adalah panas bumi (geothermal). Geothermal merupakan sumber daya panas alami, hasil interaksi antara panas yang dipancarkan batuan panas (magma) dan air tanah yang berada disekitarnya, dimana cairan yang terpanasi akan terperangkap di dalam batuan yang terletak didekat permukaan sehingga secara ekonomis dapat dimanfaatkan (Amstead, 1983). Potensi panas bumi di Indonesia sangat melimpah, karena terletak di zona tumbukan antara lempeng Eurasia dan lempeng IndoAustralia, hingga saat ini telah teridentifikasi 265 daerah prospek panas bumi di Indonesia, 138 lokasi (52,07\%) masih pada tahap penyelidikan tingkat spekulatif, 24 lokasi $(9,05 \%)$ masih pada tahap penyelidikan tingkat hipotetis, 88 lokasi (33,21\%) berpotensi sebagai cadangan panas bumi, 8 lokasi $(3,01 \%)$ siap dikembangkan menjadi potensi panas bumi, 7 lokasi $(2,64 \%)$ telah dimanfaatkan untuk pembangkit listrik tenaga panas bumi (badan geologi, 2009).

Diperkirakan energi potensi panas bumi di Indonesia mencapai 27.500,00 MW, yakni sumber potensi tersebut berada di Sumatera, Jawa, Nusa Tenggara, Maluku dan Papua. Sumatera Utara merupakan salah satu provinsi yang paling banyak memiliki potensi energi panas bumi yaitu 1.857,00 MW yang terdapat di enam kabupaten yakni, Karo, Simalungun, Tapanuli Utara, Tapanuli Selatan, Padang Lawas dan Mandailing Natal (Gunawan, 2013).

Menurut kementrian energi sumber daya mineral tahun 2011 bahwa Sumatera Utara tidak akan kekurangan sumber energi listrik jika potensi panas bumi dimanfaatkan secara maksimal. Energi panas bumi yang telah ada pengembangannya di Sumatera Utara yaitu panas bumi Sarulla (330 MW) dan Sibayak (120 MW), Dolok Marawa Kabupaten Simalungun dengan potensi cadangan terduga $38 \mathrm{MW}$.

Panas bumi salah satu energi alternatif yang dapat diperbaharui (renewable). Untuk mengatasi krisis energi khususnya di Sumatera Utara yang salah satu provinsi memiliki potensi panas bumi, seharusnya pembangkit listrik tenaga panas bumi merupakan solusi alternatif untuk menyelesaikan masalah kekurangan energi tersebut, kelebihan energi panas bumi yaitu ramah lingkungan dan termasuk energi yang tidak dapat diekspor sehingga pasokan energi listrik di negara Indonesia terus terjaga hingga ratusan tahun. Eksplorasi panas bumi dapat diketahui dengan cara menentukan nilai resistivitas batuan 
dengan menggunakan beberapa metode yakni elektromagnetik, gravitasi, seismik, geomagnetik dan geolistrik. Dari beberapa metode dalam penentuan ekplorasi panas bumi banyak kelebihan jika menggunakan metode geomagnetik dan geolistrik.

Metode geomagnet dilakukan berdasarkan pengukuran anomali geomagnet yang diakibatkan oleh perbedaan kontras suseptibilitas atau permeabilitas magnetik tubuh jebakan dari daerah sekelilingnya. Perbedaan permeabilitas relatif itu diakibatkan oleh perbedaan distribusi mineral ferromagnetic, paramagnetic dan diamagnetic. Metode geomagnet ini sensitif terhadap perubahan vertikal, umumnya digunakan untuk mempelajari tubuh intrusi, batuan dasar, urat hidrothermal yang kaya akan mineral ferromagnetic dan struktur geologi (Broto, 2011).

Metode geolistrik (resistivity) adalah metode eksplorasi geofisika yang digunakan untuk eksplorasi bahan tambang, persedian air dan panas bumi. Metode ini dirancang untuk memberikan informasi dari formasi batuan yang mempunyai anomali konduktivitas listrik. Metode resistivity dan magnetotelluric dapat digunakan untuk memetakan kecungan sedimen pada tahap awal eksplorasi minyak bumi (Broto, 2011).

Dalam eksplorasi panas bumi, metode geolistrik digunakan untuk mengetahui prospek daerah panas bumi, yakni mempelajari sifat aliran listrik pada batuan di bawah permukaan bumi. Prinsip dasarnya yaitu dengan menginjeksikan arus ke bawah permukaan melalui dua elektroda arus, dan mengukur besar tegangan di antara dua elektroda potensial (Arnata, 2012).

Dari penelitian sebelumnya metode yang efektif untuk mengetahui titik prospek panas bumi yaitu menggunakan metode geomagnet dan geolistrik. Salah satu daerah prospek panas bumi terdapat di kabupaten
Simalungun, yang secara geografis terletak di $02^{0} 36^{\prime} 15^{\prime \prime}-03^{0} 18^{\prime} 06^{\prime \prime}$ LU dan 98032'06"-99034'28" BT. Adanya titik prospek panas bumi daerah Simalungun dikarenakan berada pada posisi silang kawasan palung pasifik barat, sehingga terdapat sumber energi panas kawah putih dan kawah biru, salah satu daerah yang berpotensi adanya geothermal tepatnya di desa Tinggi Raja kelurahan Dolok Morawa kecamatan Silau Kahean kabupaten Simalungun.

Dusun Bahoan merupakan salah satu daerah disekitar panas bumi yang tidak mendapatkan pasokan energi listrik. Sehingga perlu dilakukan penelitian sebagai bahan pertimbangan pemerintah untuk membuat pembangkit listrik tenaga panas bumi supaya dusun Bahoan tidak mengalami kekurangan energi dan dapat mengembangkan daerah di sekitar panas bumi yang berpengaruh pada kemajuan dibidang transportasi, komunikasi dan teknologi, dengan adanya pembangkit listrik disuatu daerah maka akan mempercepat kemajuan pembangunan. Jikalau potensi ini tidak dikembangkan maka pasokan listrik akan selalu mengalami kekurangan dan daerah sekitar menjadi tertinggal dalam hal teknologi dan komunikasi.

Mengidentifikasi panas bumi di daerah dusun Bahoan diharapkan dapat menjadi solusi alternatif permasalahan energi. penelitian ini dilakukan sebagai bahan masukan dan menjadi solusi alternatif penyelesaian energi Di Dusun Bahoan Kecamatan Silau Kahean Kabupaten Simalungun”.

\section{METODE PENELITIAN Peralatan yang digunakan}

Dalam melakukan penentuan struktur bawah permukan geothermal, peralatan paling utama yang digunakan adalah geomagnet dan geolistrik. Peralatan ini digunakan untuk mengukur nilai magnetik serta 
:Wahyu Azhar Ritonga dan Muhammad Kadri, Penentuan Struktur Bawah Permukaan Daerah Geotermal Menggunakan Metode Geomagnet dan Geolistrik

kelistrikan pada daerah penelitian. Global Positioning System (GPS) Peralatan ini digunakan untuk mengukur posisi titik pengukuran yang meliputi bujur, lintang.

\section{Pengolahan Data}

\section{Geolistrik}

Teknik pengambilan data dalam penggunaan metode geolistrik yaitu: Konfigurasi geolistrik metode tahanan jenis yang digunakan yaitu konfigurasi Schlumberger dimana elektrodaelektroda potensial $\left(\mathrm{P}_{1}-\mathrm{P}_{2}\right)$ diam pada suatu tempat garis sentral $A B$, sedangkan untuk elektroda-elektroda arus $\left(\mathrm{C}_{1}-\mathrm{C}_{2}\right)$ digerakkan secara simetri keluar dalam langkah-langkah tertentu dan sama. Pemilihan konfigurasi ini didasarkan atas prinsip kemudahan dalam pengambilan data maupun dalam analisisnya. Cara pengambilan datanya adalah sebagai berikut:

Cara pengambilan datanya adalah sebagai berikut:

1. Mendownload dan mengambil data dari Ares

2. Mengeksport data ke res2dinv

3. Mengola data menggunakan res2dinv

Dari data pengukuran dan perhitungan yang didapat dilapangan, kemudian diinterpretasikan menggunakan software res2dinv untuk memperlihatkan anomali bawah permukaan area yang diukur. Software res2dinv digunakan untuk menampilkan profil (anomali 2-D) sehingga data pengukuran yang kita dapat dari lapangan menggunakan Mapping.

Data lapangan menggunakan geolistrik ARES (automatic resistivity meters ) dapat diperoleh dengan cara:

1. Data hasil download yang didapatkan dari alat geolistrik Ares, akan diketahui nilai resistivitas semu $\left(\rho_{s}\right)$.

2. Dari data tersebut diolah dengan menggunakan metode optimasi least-square non-linier yang ada pada software Res2Dinv untuk 2D

3. Dari invers 2D tersebut diperoleh gambar penampang resistivitas yang menggambarkan atau mencitrakan distribusi resistivitas bawah permukaan tanah yang diteliti, setiap lintasan akan didapatkan gambar penampang melintang resistivitas.

Dari gambar yang dihasilkan pada pengolahan dengan software Res2Dinv, akan dibandingkan berdasarkan distribusi resistivitasnya yang ditunjukkan dengan citra warna yang berbeda dan disertai dengan kedalaman lapisan tanah, kemudian dibandingkan dengan kondisi lokasi penelitian

Untuk mengetahui nilai resistivitas semu $\left(\rho_{s}\right)$ dapat digunakan persamaan sebagai berikut:

Dengan faktor geometri (K) adalah :

$$
\begin{gathered}
\mathrm{K}=\left[\frac{1}{2 \pi}\left(\frac{1}{r 1}-\frac{1}{r 2}\right)-\left(\frac{1}{r_{3}}-\frac{1}{r^{4}}\right)\right]^{-1} \text { atau } \\
\mathrm{K}=\frac{2 \pi}{\left(\frac{1}{r^{2}}-\frac{1}{r^{2}}\right)-\left(\frac{1}{r_{3}}-\frac{1}{r^{4}}\right)}
\end{gathered}
$$

Sehingga untuk mencari resistivitas semu $\left(\rho_{s}\right)$ adalah

$$
\begin{aligned}
&\left(\rho_{s}\right)=K \frac{\Delta V}{I} \\
& \text { Dimana: } \\
& \mathrm{K} \quad= \text { Faktor geometri } \\
& \rho_{s}=\text { Resistivitas semu }(\mathrm{Ohm} \mathrm{m}) \\
& \Delta V=\text { Potensial }(\mathrm{V}) \\
& \mathrm{I} \quad=\text { Arus }(\mathrm{A}) \\
& \mathrm{r}=\text { Jarak }
\end{aligned}
$$

\section{Geomagnet}

Teknik pengambilan data dalam penggunaan metode geomagnet yaitu: dengan cara menentukan grid yang akan diteliti dan Data magnetik yang diperoleh dari pengukuran di lapangan berupa data kuat medan magnetik dalam nT. Data lapangan yang diperoleh terlebih dahulu dilakukan: 
1. Koreksi harian ( diurnal correction)

Cara yang dilakukan untuk mendapatkan nilai koreksi harian dengan membuat grafik intensitas medan (I) versus waktu (t) dari hasil pengukuran di medan stasiun base



Gambar 1. Grafik Intensitas Magnetik (I) Versus Waktu (t)

Harga penyimpangan diperoleh dengan persamaan interpolasi berikut:

$$
I_{f}=\left[\left(\frac{t_{f}-t_{1}}{t_{2}-t_{1}}\right)\left(I_{2}-I_{1}\right)\right]
$$

Kemudian diperoleh besar koreksi variasi harian dengan persamaan:

$$
T_{v h}=I_{1} \pm I_{f}
$$

\section{Koreksi IGRF}

Untuk memperoleh nilai IGRF pada tiap titik pengamatan menggunakan software NOAA.

Persamaan koreksi yaitu sebagai berikut:

$$
\Delta H=\Delta H_{\text {obs }} \pm \Delta H_{\text {harian }}-H_{0}
$$

\section{Koreksi Topografi (terrain)}

Untuk daerah kutub sekitar $\pm 0.03 \gamma /$ $m$ dan untuk daerah ekuator sekitar $\pm 0,015 \gamma / \mathrm{m}$. Keterangan : dimana $1 \gamma=1$ nano tesla. Karena penelitian berada di daerah aquator, maka koreksi topografinya

$$
T_{T}=T_{v h}-(\Delta h * 0,015 \gamma)
$$

4. Peta Anomali magnet

Dari harga intensitas medan teramati dihitung harga medan anomali

$$
\Delta H=H^{*}-H_{0}
$$

5. Harga Anomali Magnet

Harga medan anomali kemudian dipetakan (peta anomali magnetik), intensitas magnet dilapangan dapat dihitung dengan menggunakan persamaan:

$$
\Delta H=T_{T}-H_{I G R F}
$$

6. Suseptibilitas Magnet Batuan

$$
k=\frac{\vec{I}}{H}
$$

Dimana:

$k=$ Suseptibilitas medan magnet di titik pengukuran $\vec{I}=$ Intensitas anomali magnet bumi dititik pengukuran (gamma). $H=$ Harga intensitas magnet bumi rata-rata di daerah survei, yang merupakan harga rata-rata di stasion base (gamma).

\section{HASIL PENELITIANDAN PEMBAHASAN}

1. Hasil Penelitian Geomagnet

Hasil penelitian survei magnet bumi di daerah dusun Bahoan kecamatan Silau Kahean Kabupaten Simalungun adalah data topografi dengan menggunakan GPS Garmin Etrex, data pengamatan medan magnet bumi di field diperoleh dari hasil pembacaan Proton Precession Magnetometer (PPM) Type elsec 770 dan data pengamatan magnet bumi di base stasiun diperoleh dari hasil pembacaan PPM model G-856 AX. Berdasarkan peta geologi daerah lokasi penelitian umumnya terdiri atas batu gamping, batu pasir, batu lempung dan batu lanau.

\section{A. Deskripsi Data Geomagnetik \\ 1. Pola Penyebaran Anomali Magnet Bumi}

Anomali medan magnet hasil perhitungan yang di dapat ditampilkan 
:Wahyu Azhar Ritonga dan Muhammad Kadri, Penentuan Struktur Bawah Permukaan Daerah Geotermal Menggunakan Metode Geomagnet dan Geolistrik

dalam bentuk peta kontur anomali dengan menggunakan software surfer 10. Dapat dilihat pada gambar 4.1. berikut:

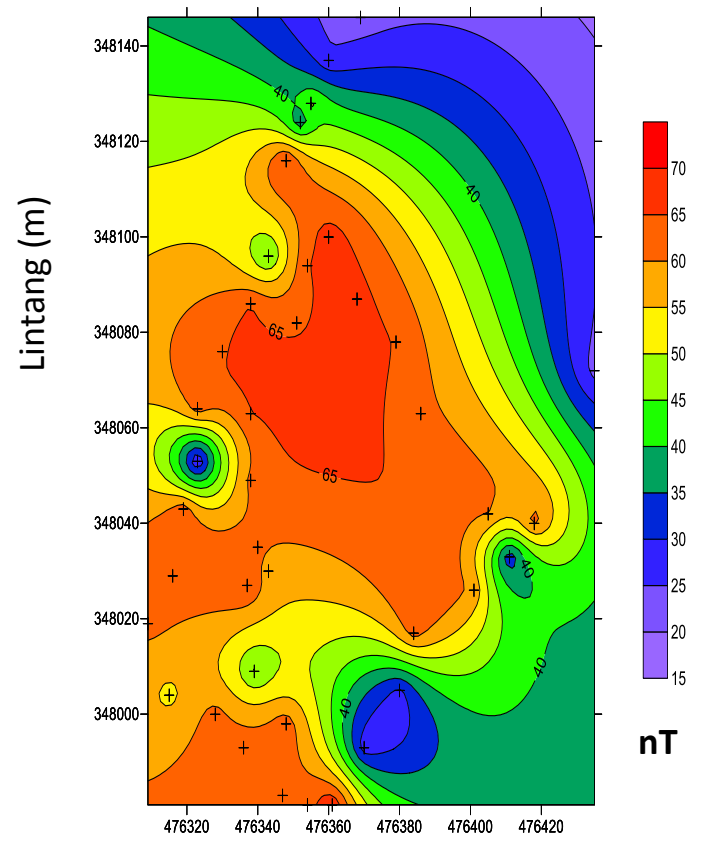

Bujur (m)

Gambar 2. Pola Penyebaran Anomali Magnet Bumi di Lokasi Survei

Gambar 2. menunjukkan daerah survei dengan anomali rendah berada pada titik pada titik (M1), yaitu $22,75 \mathrm{nT}$ dan anomali tinggi (M19), yaitu 69,92 nT. Harga anomali magnet rendah yang didapat pada daerah survei ditafsirkan merupakan daerah yang erat kaitannya dengan terbentuknya manifestasi panas bumi di daerah tersebut.

\section{Suseptibilitas (k) Batuan Daerah Bahoan}

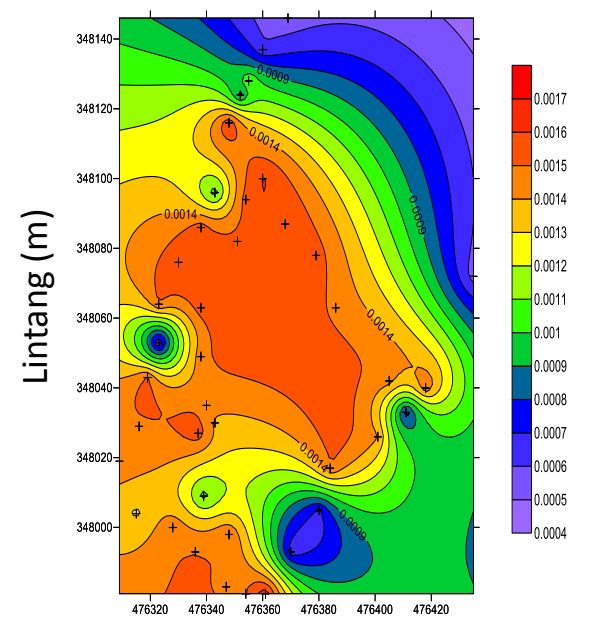

Gambar 3. Peta Kontur Suseptibilitas

Gambar 3. menunjukkan daerah survei panas bumi Bahoan dengan suseptibilitas dari paling rendah sampai suseptibilitas paling tinggi yaitu: $0,000543621 \times 10^{3}$ s.d $0,001670689 \times 10^{3}$.

\section{Interpretasi Data Geomagnet}

Interpretasi diperlukan untuk menggambarkan struktur bawah permukaan daerah pengukuran data survei.

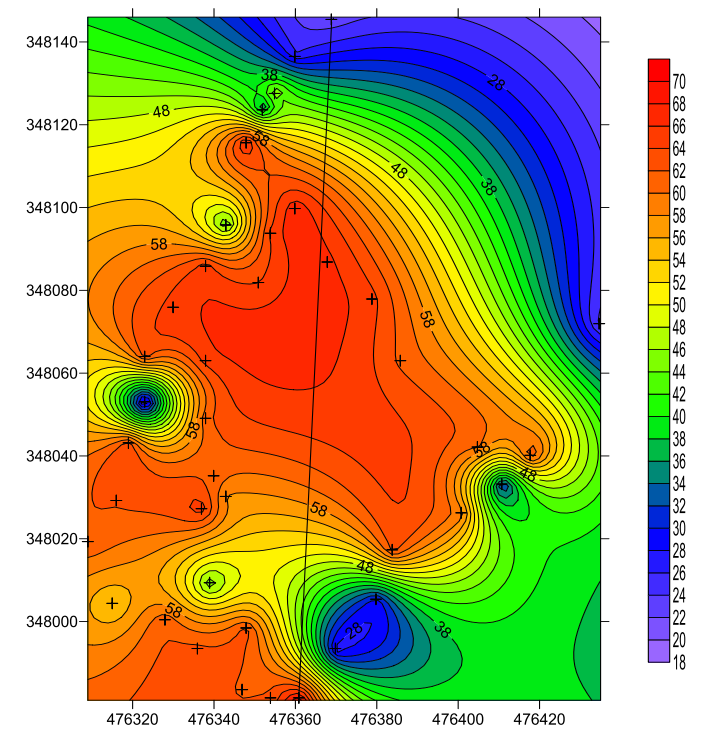

Gambar 4. Peta kontur anomali dengan sayatan A-A' 
Gambar 4. menunjukan sayatan AA' pada suseptibilitas yang disayat berdasarkan geologi daerah penelitian dan interpretasi

Interpretasi kuantitatif bertujuan untuk menentukan litologi daerah penelitian. Lotologi ini dapat ditentukan dengan nilai suseptibilitas hasil pemodelan. Interpretasi ini dilakukan dengan membuat model menggunakan software Mag2DC, sehingga akan diperoleh gambar 4.4.

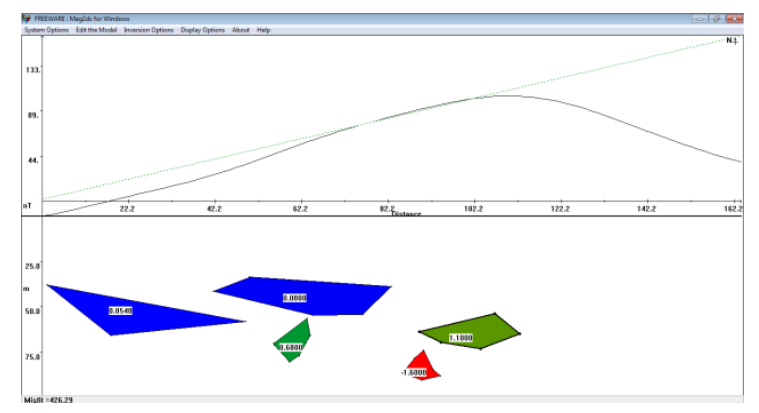

Gambar 5. Model Penampang Geomagnetik Menggunakan Mag2DC

Gambar 5. Menunjukkan model penampang yang melintang $\mathrm{AA}^{\prime}$ dimana terdapat sumbu x dan sumbu y. Sumbu $\mathrm{x}$ merupakan nilai jarak lintasan, sumbu y negatif merupakan nilai kedalaman. Hasil pemodelan dari nilai suseptibilitas yang diperoleh menunjukkan jenis batuan sedimen dengan nilai suseptibilitas $(0,00054 ; 0,00085 ; 0,0006$; $0,00068 ; 0,0016)$.

\section{Pembahasan Geolistrik}

Secara interpretasi kuantitatif maka daerah ini dapat digambarkan dengan melihat pendukung penelitian berupa peta geologinya. Berdasarkan peta geologi lembar medan daerah Bahoan didominasi oleh: batu gamping, batu pasir, batu lempung dan batu lanau.

Tampilan 2-D hasil dari pengolahan data menggunakan Software Res2Dinv tersebut terdiri dari tiga kontur Isoresistivitas pada penampang kedalaman semu (Pseudodep thsection), yaitu:
1.Penampang pertama menunjukkan kontur pengukuran resistivitas semu (measured apparent resistivity), yaitu data resistivitas semu yang diperoleh dari pengukuran lapangan.

2.Penampang kedua menunjukkan kontur resistivitas dari hasil perhitungan (calculate apparent resistivity).

3.Penampang ketiga menunjukkan kontur resistivitas sebenarnya yang diperoleh setelah melalui proses pemodelan inversi (inverse model resistivity section). Pada daerah penelitian dilakukan dua lintasan, yakni:

\section{Lintasan I}

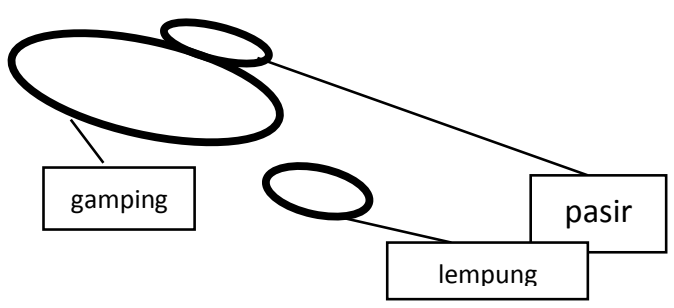

Data yang diperoleh dengan menggunakan alat geolistrik (Restivity Meter), adalah nilai resistivitas semu bervariasi dikarenakan struktur bawah permukaan sangat bervariasi, nilai resistivity $0,00 \Omega m$ sampai $7000 \Omega m$ panjang lintasan 155 meter dengan 32 elektroda dan jarak antara elektroda 5 meter dengan kedalaman maksimal 28,7 m. Diinversikan dengan software Res2Dinv diperoleh gambar penampang 4.5. berikut: 


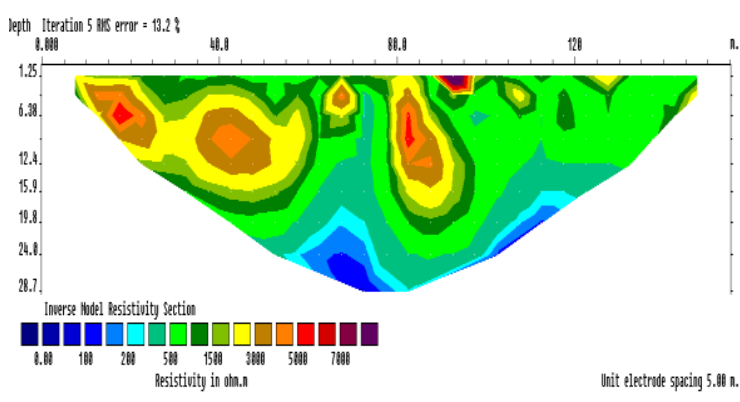

Gambar 6. Penampang Kontur Restivitas Lintasan I

Berdasarkan gambar 6. untuk nilai resistivitas $0,00-100 \Omega m$ terletak pada kedalaman 21-28,7 m dengan jarak 60$78 \mathrm{~m}$ ditafsirkan sebagai lempung. Nilai resistivitas $150-200 \Omega m$ terletak pada kedalaman 3,81-24,5 m dengan jarak 116-130 m ditafsirkan sebagai lanau. Nilai restivitas $350-500 \Omega m$ terletak pada kedalaman 1,25-3,82 $\mathrm{m}$ dengan jarak 45-60 m ditafsirkan sebagai batu pasir, dan untuk nilai restivitas $>2250$ $\Omega m$ ditafsirkan sebagai batu gamping yang terletak pada kedalaman 1,2515,9 m dengan jarak antara 7-61 m.

Hasil penampang resistivitas menunjukkan bahwa adanya perbedaan nilai restivitas pada tiap lapisan. Untuk lintasan 1 umumnya didominasi oleh lapisan yang memiliki nilai resistivitas $>2250 \Omega m$ yang ditafsirkan sebagai batu gamping. Anomali rendah terdapat pada kedalaman 21-28,7 m dengan jarak 60$78 \mathrm{~m}$ memiliki nilai resistivitas $0,00-100$ $\Omega m$ dengan warna biru tua sampai biru muda Anomali rendah ini ditafsirkan sebagai lempung.

Menurut lenat (1999), nilai resistivitas berbanding terbalik dengan nilai konduktivitas batuan, dimana semakin konduktif suatu batuan maka nilai resistivitasnya akan semakin kecil. Hal ini disebabkan adanya porositas yang besar yang terisi oleh fliuda panas bumi terutama air dalam kondisi panas tinggi.

\section{Lintasan II}

Data yang diperoleh dengan menggunakan alat geolistrik (Restivity Meter), adalah nilai resistivitas semu bervariasi dikarenakan struktur bawah permukaan sangat bervariasi, nilai resistivity $0,00 \Omega m$ sampai $7000 \Omega m$. panjang lintasan 155 meter dengan 32 elektroda dan jarak antara elektroda 5 meter dengan kedalaman maksimal 28,7 m. Diinversikan dengan software Res2Dinv diperoleh gambar 7 penampang berikut:



Gambar 7. penampang kontur restivitas lintasan II

Berdasarkan gambar 4.6. untuk nilai resistivitas $50-100 \Omega m$ terletak pada kedalaman 20-28,7 m dengan jarak 77,5- $89 \mathrm{~m}$ ditafsirkan sebagai lempung. Nilai resistivitas $150-200 \Omega m$ terletak pada kedalaman 9,39- 28,7 $\mathrm{m}$ dengan jarak 68- 97,5 m ditafsirkan sebagai lanau. Nilai restivitas 500-1500 $\Omega m$ terletak pada kedalaman 1,25- $28,7 \mathrm{~m}$ dengan jarak 7- 66,5 m ditafsirkan sebagai batu pasir, dan untuk nilai restivitas $>2250 \Omega m$ ditafsirkan sebagai batu gamping yang terletak pada kedalaman 1,25- 21,5 m dengan jarak antara 44-75 m.

Hasil penampang resistivitas menunjukkan bahwa adanya perbedaan nilai restivitas pada tiap lapisan. Untuk lintasan II umumnya didominasi oleh lapisan yang memiliki nilai resistivitas $>2250 \Omega m$ yang ditafsirkan sebagai batu gamping. Anomali rendah terdapat pada 
kedalaman 20-28,7 m dengan jarak 77,5$89 \mathrm{~m}$ memiliki nilai resistivitas 50-100 $\Omega m$ dengan warna biru tua sampai biru muda Anomali rendah ini ditafsirkan sebagai lempung.

Dapat ditafsirkan lapisan yang berpotensi sebagai geothermal adalah lapisan yang berada pada kedalaman 2028,7 $\mathrm{m}$ dengan jarak 77,5-89 $\mathrm{m}$ dengan nilai resistivitas $50-100 \Omega m$ yakni lapisan lempung. Berdasarkan hasil analisa terlihat bahwa pada daerah penelitian terdapat tiga lapisan tanah yang tersusun atas lempung, pasir dan gamping. Hasil inverse dari kedua lintasan didominasi oleh batuan gamping.

\section{KESIMPULAN}

Dari hasil penelitian yang dilakukan maka dapat diambil kesimpulan antara lain:

1. Nilai Anomali magnet di derah penelitian berkisar antara 22,75 nT pada koordinat $476369 \mathrm{~N}$ dan 348146 E sampai 69,92 nT pada koordinat $476361 \mathrm{~N}$ dan 347981 E.

2. Nilai resistivitas pada lintasan I antara $0,00^{-} \quad 100 \Omega m$ dan lintasan II antara 50-100 $\Omega m$ yakni lapisan lempung sebagai zona konduktif manifestasi panas bumi. Untuk lapisan penudung berupa batu gamping.

3. Berdasarkan nilai suseptibilitas pada daerah dusun Bahoan jenis batuan yang terdapat pada daerah penelitian tersebut 0,00054, 0,0006, 0,0016 dimana model lapisan struktur bawah permukaan terdiri dari batuan pasir, lempung dan gamping.

4. Berdasarkan nilai resistivitas yang diperoleh nilai resistivitas (0,00-100) $\Omega m$ dan model lapisan batuan lempung. Nilai resistivitas (150-200) $\Omega m$ model lapisan batuan lanau. Nilai restivitas $(350-500) \Omega m$ model lapisan pasir, dan nilai restivitas $>2250 \Omega m$ model lapisan batu gamping.

5. Hasil dari nilai suseptibilitas dan nilai resistivitas pada daerah Dusun Bahoan memiliki lapisan yang sesuai.

\section{REFERENSI}

Arnata, D.P., Musa, D.T., Sabhan., (2012), Identifikasi Sistem Panas Bumi Di Desa Masaingi Dengan Menggunakan Metode Geolistrik, Jurnal Natural Science Vol.1 (1) 1-6.

Badan Geologi, (2009), Panas Bumi Di Indonesia:http://psdg.bgl.esdm.go. id. Diakses tanggal 6 september 2015, Jam 23.55 WIB.

Broto, S., Putranto, T.T., (2011), Aplikasi Metode Geomagnet Dalam Eksplorasi Panas Bumi, Teknik Vol.32 No.1 ISSN: 08521697.

Budiyanti, E., (2014), Mengatasi Krisis Listrik Di Jawa dan Sumatera. Info Singkat Ekonomi dan Kebijakan Publik Vol. VI, 05/I/P3DI

Gunawan, H, (2013), Potensi panas Bumi di Samosir Siap Dilelang, Tribunnews:

http://tribunnews.com diakses tanggal 02 oktober 2015, Jam 16.00 WIB.

Lenat, J.F, dkk, (1999), Geoelectrical structur of the central zone of Piton de la fournaise volcano (Reunion), Bull Volcanol, 62: 7589 
:Wahyu Azhar Ritonga dan Muhammad Kadri, Penentuan Struktur Bawah Permukaan Daerah Geotermal Menggunakan Metode Geomagnet dan Geolistrik 